\title{
RAGAM FENOTIPE IKAN TENGADAK Barbonymus schwanenfeldii (BLEEKER 1854)HASIL SILANG LUAR
}

\section{[Phenotype Variation of the Tinfoil Barb Barbonymus schwanenfeldii (Bleeker 1854)} From Outbreed Result]

\author{
Firda Amalia Sukma** , M.H. Fariddudin Ath-Thar ${ }^{2}$, Odang Carman ${ }^{1}$, dan Deni Radona* ${ }^{2 \bowtie}$ \\ ${ }^{1}$ Departemen Budidaya Perairan, FPIK IPB, Jln. Agatis Kampus IPB Dramaga 16680 \\ ${ }^{2}$ Balai Penelitian dan Pengembangan Budidaya Air Tawar, Jln. Sempur No. 1 Bogor 16151 \\ email: deniradona_kkp@yahoo.com

\section{ABSTRACT}

Outbreed may increase genetic diversity and produce better offspring. Meanwhile, genetic diversity can be inferred from phenotypes variability. This study aimed to analyze the diversity of phenotypic characters from four populations of tinfoil barb outbreed, namely Java $(\mathrm{J})$, Kalimantan $(\mathrm{K})$, + Java $\times \widehat{O}$ Kalimantan $(\mathrm{JK})$ and + Kalimantan $\times \hat{\delta} \mathrm{Java}(\mathrm{KJ})$.Analysis of the phenotypic diversity was calculated based on truss morphometric on 30 individuals sampled from each populations. The growth and survival rate were measured for 40 days reared. The study was conducted experimentally using a completely randomized design (CDR) with three replications.Rearing four

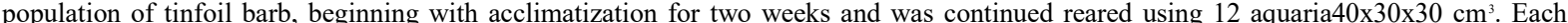
aquaria was filled with 10 individual seeds $/ 20 \mathrm{~L}^{-1}$ water with the size of $18,66 \pm 1,34 \mathrm{~g}$ weight and $8,28 \pm 0,34 \mathrm{~cm}$ of length. Feeding was done three times a day on ad-libitum using commercial pellet with protein content of $31-33 \%$. The result of the canonical function analysis of truss morfometrik thetinfoil barb on 21 characteris indicated that the individual morphological characterof population of the tinfoil barb outbreed ( $\mathrm{JK}$ and $\mathrm{KJ}$ ) interrelated with each other.The highest sharing component value of inter population was obtained on the fish from outbreed of KJ and JK $(13,3 \%)$, while the highest of intra population was obtained of $\mathrm{K}(96,7 \%)$ and the lowest of JK $(86,7 \%)$. The highest survival rate $(100 \%)$ was recorded on the JK population and significantly different $(\mathrm{P}>0,05)$ with survival rate of $90 \%$ observed in the J population.

Key words: outbreed, truss morphometric, survival, rearing.

\section{ABSTRAK}

Silang luar dapat meningkatkan keragaman genetik sehingga menghasilkan keturunan dengan kualitas lebih baik. Sementara itu, ragam genetik dapat direfleksikan dari keragam fenotipe. Penelitian ini bertujuan untuk menganalisis ragam fenotipe empat populasi ikan tengadak hasil silang luar, yaitu Jawa $(\mathrm{J})$, Kalimantan $(\mathrm{K})$, $q$ Jawa $\times \hat{\delta}$ Kalimantan $(\mathrm{JK})$ dan $q$ Kalimantan $\times \hat{\delta} \mathrm{Jawa}(\mathrm{KJ})$.Analisis keragaman fenotipe dilakukan dengan menggunakan metode truss morfometrik dengan 30 sampel ikan dari masing-masing populasi. Pertumbuhan dan tingkat kelangsungan hidup diukur selama 40 hari pemeliharaan.Penelitian dilakukan secara eksperimental dengan menggunakanrancangan acak lengkap (RAL) dan tiga kali ulangan. Pemeliharaan empat populasi ikan tengadak, diawali dengan aklimatisasi selama dua minggu dan dilanjutkan pemeliharaan dengan menggunakan 12 buah akuarium berukuran 40x30x30 cm. Setiap akuarium ditebar benih sebanyak 10 ekor/20 L-1 air yang berukuran bobot $18,66 \pm 1,34 \mathrm{~g}$ dan panjang $8,28 \pm 0,34 \mathrm{~cm}$.Pemberian pakan dilakukan sebanyak tiga kali sehari secara ad-libitum menggunakan pellet komersial dengan kandungan protein sebesar 31-33\%. Hasil analisis fungsi kanonikal truss morfometrik ikan tengadak pada 21 karakteristik terukur menunjukkan karakter morfologi individu pada populasi ikan tengadak hasil silang luar (JK dan KJ) saling bersinggungan satu sama lain. Nilai sharing component inter populasi tertinggi diperole h pada ikan tengadak hasil silang luar yaitu KJ dan JK (13,3\%) sedangkan intra populasi tertinggi $(96,7 \%)$ tercatat pada K dan terendah $(86,7 \%)$ pada populasi JK. Sintasan tertinggi diperoleh pada populasi JK $(100 \%)$ dan berbeda nyata $(\mathrm{P}>0,05)$ dengan sintasan $90 \%$ yang diamati pada populasi $\mathrm{J}$.

Kata kunci: silang luar, truss morfometrik, sintasan, pemeliharaan.

\section{PENDAHULUAN}

Ikan tengadak Barbonymus schwanenfeldii (Bleeker, 1854) merupakan spesies asli Asia Tenggara (Dewantoro, 2015; Allen, 2012), dan di Indonesia ditemukan di perairan tawar Sumatera, Kalimantan dan pernah dilaporkan di Jawa (Gustiano et al., 2015; Kusmini et al., 2016; Radona et al., 2016; 2017). Selain sebagai ikan konsumsi, ikan tengadak juga dapat dimanfaatkan sebagai ikan hias. Di Indonesia, budidaya ikan tengadak sudah dilakukan sejak tahun 2010 tetapi belum dilaksanakan secara intensif. Sejauh ini, kemampuan adaptasi ikan tengadak pada lingkungan budidaya masih tergolong rendah. Kusmini et al. (2015) melaporkan bahwa kelangsungan hidup ikan tengadak pada umur 50-60 hari sebesar $69,28 \pm 19,64 \%$ dengan pertumbuhan hanya mencapai ukuran 1-2 cm.

Rendahnya produktifitas ikan tengadak menyebabkan berkurangnya suplai produk dari kegiatan budidaya, sehingga kebutuhan konsumsi tidak tercukupi. Upaya pengembangan budidaya ikan tengadak terus dilakukan melalui pendekatan secara genetik diantaranya silang luar. Silang luar merupakan perkawinan antara dua individu yang tidak sekerabat untuk mendapatkan keturunan yang lebih baik, yang mempunyai keunggulan pertumbuhan dan kelangsungan hidup (Ismi et al., 2014; Tave, 1993). Silang luar pada umumnya dilakukan untuk pengkayaan ragam genetik populasi 
dan meningkatkan heterosigositas, sehingga berimplikasi pada peningkatan kemampuan adaptasi, keragaan pertumbuhan, dan tingkat kelangsungan hidup (Lorenzen et al., 2012; Wedemeyer, 2001).

$\begin{array}{lcrr}\text { Ragam } & \text { genetik } & \text { dapat diidentifikasi } \\ \text { berdasarkan } & \text { pengukuran } & \text { karakteristik fenotipe } \\ \text { morfologi } & \text { berdasarkan } & \text { morfometrik dan }\end{array}$
pertumbuhan (Sneath, 1995). Karakter fenotipe dapat mencerminkan tingkat kebugaran populasi sehingga memudahkan untuk melakukan seleksi sumberdaya genetik dalam proses budidaya selanjutnya. Beberapa penelitian terkait ragam genetik ikan tengadak sudah dilakukan, diantaranya kajian genotipe dan morfometrik ikan tengadak asal Jawa, Kalimantan, dan Sumatera (Radona et al., 2016). Penelitian ini bertujuan untuk menganalisis karakter fenotipe ikan tengadak hasil silang luar antara populasi Jawa dan Kalimantan secara resiprokal.

\section{BAHAN DAN CARA KERJA}

Penelitian dilakukan di Instalasi Penelitian Plasma Nutfah Perikanan Air Tawar, Balai Riset Perikanan Budidaya Air Tawar dan Penyuluhan Perikanan Bogor, pada Bulan Januari-April 2017.

\section{Sampel ikan uji}

Ikan uji yang digunakan merupakan benih ikan tengadak hasil silang luar antara populasi Jawa dan Kalimantan secara resiprokal, terdiri dari empat populasi yaitu A) ikan tengadak $q$ Jawa $\times \widehat{~ J a w a ~(J), ~ B) ~}$ q Kalimantan $\times \widehat{\jmath}$ Kalimantan $(\mathrm{K}), \mathrm{C})$ q Jawa $\times \hat{\jmath}$ Kalimantan (JK), dan D) $q$ Kalimantan $\times$ ઈ Jawa $(\mathrm{KJ})$. Ikan uji yang digunakan memiliki bobot ratarata $18,66 \pm 1,34 \mathrm{~g}$ dengan panjang rata-rata $8,28 \pm 0,34 \mathrm{~cm}$.

\section{Pengamatan morfometrik}

Morfometrik dilakukan terhadap 30 ekor sampel ikan setiap populasi. Truss morfometrik diukur dengan metode pengukuran dan penentuan titik-titik truss berdasarkan Radona et al. (2017) yang meliputi 21 karakter terukur, A1 (ujung mulut-ujung operculum bawah), A2 (ujung mulut-batas akhir tulang kepala), A3 (ujung mulut-sirip ventral), A4 (ujung operculum bawah-batas akhir tulang kepala), A5 (ujung operculum bawah-sirip ventral), A6 (batas akhir tulang kepala-sirip ventral), B1 (batas akhir tulang kepala-awal sirip dorsal), B3 (batas akhir tulang kepala-awal sirip anal), B4 (sirip ventralawal sirip dorsal), B5 (sirip ventral-awal sirip anal), B6 (awal sirip dorsal-awal sirip anal), C1 (awal sirip dorsal-akhir sirip dorsal), C3 (awal sirip dorsalakhir sirip anal), C4 (awal sirip anal-akhir sirip dorsal), C5 (awal sirip anal-akhir sirip anal), C6 (akhir sirip dorsal-akhir sirip anal), D1 (akhir sirip dorsal-awal sirip ekor atas), D3 (akhir sirip dorsalawal sirip ekor bawah), D4 (akhir sirip anal-awal sirip ekor atas), D5 (akhir sirip anal-awal sirip ekor bawah) dan D6 (awal sirip ekor atas-akhir sirip ekor bawah). Pembuatan titik-titik truss dilakukan dengan cara meletakkan ikan di atas kertas yang telah dilapisi plastik bening dan styrofoam. Masingmasing titik ditandai dengan menggunakan jarum sesuai dengan pola truss morfometrik (Gambar 1). Hasil pengukuran truss morfometrik seluruh karakter dikonversi kedalam rasio dengan membagi nilai karakter terukur terhadap nilai panjang standar (PS).

\section{Keragaan Pertumbuhan}

Parameter pertumbuhan yang diamati meliputi: pertumbuhan panjang mutlak $(\mathrm{cm})$, bobot mutlak $(\mathrm{g})$, laju pertumbuhan spesifik (\%), tingkat kelangsungan hidup dan heterosis (\%). Penelitian dilakukan secara eksperimental dengan menggunakan rancangan acak lengkap (RAL) dan tiga kali ulangan. Pemeliharaan empat populasi ikan tengadak diawali dengan aklimatisasi selama dua minggu dan dilanjutkan pemeliharaan selama 40 hari. Penelitian menggunakan 12 buah akuarium berukuran $40 \times 30 \times 30 \mathrm{~cm}^{3}$ dengan ketinggian air berkisar $20 \mathrm{~cm}$, masing-masing akuarium diberi aerasi dengan intensitas yang sama. Ikan uji yang digunakan berukuran bobot $18,66 \pm 1,34 \mathrm{~g}$ dan panjang $8,28 \pm 0,34 \mathrm{~cm}$. Jumlah ikan yang ditebar pada setiap akuarium adalah 10 ekor. Pemberian pakan dilakukan sebanyak tiga kali sehari pada pukul 07.00, 12.00, dan 17.00 WIB secara ad-libitum menggunakan pellet komersial dengan kandungan protein sebesar 31-33\%. Kegiatan sampling dilakukan dengan mengukur bobot dan panjang ikan setiap sepuluh hari. Pengukuran bobot ikan dilakukan dengan menggunakan timbangan digital dengan tingkat ketelitian 0,01 g. Pengukuran panjang ikan dilakukan dengan menggunakan penggaris 


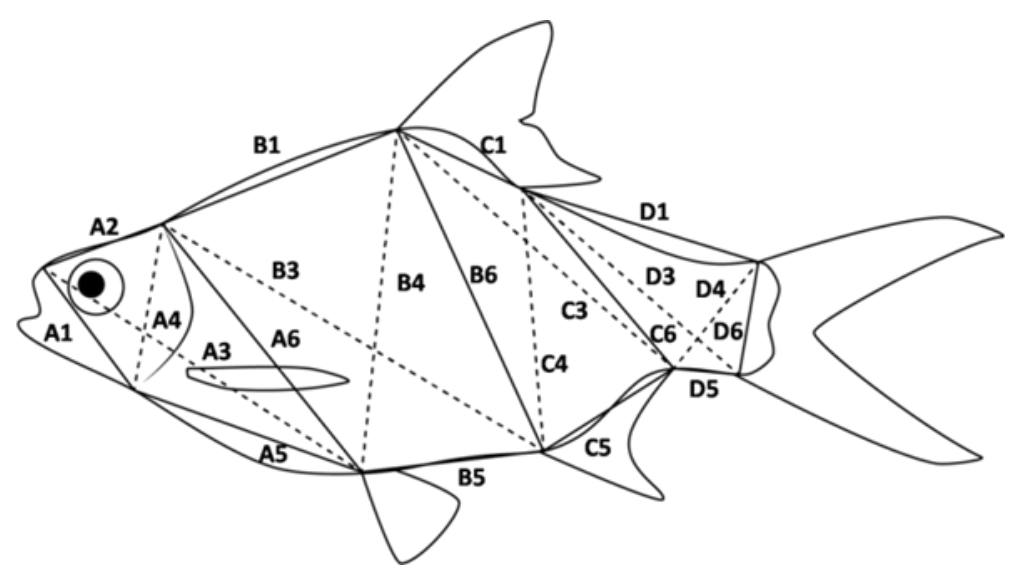

Gambar 1. Titik pengukuran truss morfometrik pada ikan tengadak (Measurement point of truss morphometric on tinfoil barb)

dengan tingkat ketelitian $0,5 \mathrm{~mm}$. Untuk data kelangsungan hidup diamati setiap hari berdasarkan kematian ikan, sedangkan nilai heterosis berdasarkan persamaan Tave (1993).

\section{Analisis data}

Karakter truss morfometrik dianalisis secara kuantitatif menggunakan program ImageJ (https:// imagej.nih.gov/ij/download.html). Sebaran karakter truss morfometrik (intra- dan interpopulasi) dan indeks keseragaman (sharing component) dilakukan dengan ANOVA menggunakan SPSS versi 18 serta ditampilkan dalam diagram fungsi kanonikal. Data pertumbuhan dan tingkat kelangsungan hidup ditabulasi menggunakan Microsoft Excel 2010, dianalisa dengan analisis varian (ANOVA) menggunakan program SPSS 22.0 kemudian dilakukan uji lanjut Tukey dengan tingkat kepercayaan $95 \%$.

\section{HASIL}

\section{Truss morfometrik ikan tengadak hasil silang} luar

Keragaman fenotip terhadap 21 karakter pada ikan tengadak hasil silang luar disajikan pada Tabel 1. Keragaman morfometrik dinyatakan dalam koefisien keragaman (CV). Hasil analisis Wilks lambda menunjukkan kesamaan pada lima karakter terukur.

Nilai sharing component intra populasi dan inter populasi ikan tengadak disajikan pada Tabel 2. Nilai sharing component inter populasi tertinggi diperoleh pada ikan tengadak hasil silang luar yaitu KJ dan JK $(13,3 \%)$ sedangkan intra populasi tertinggi diperoleh pada $\mathrm{K}(96,7 \%)$ dan terendah pada JK $(86,7 \%)$.

Hasil analisis fungsi kanonikal (Gambar 2) memperlihatkan bahwa karakter morfologi individu pada populasi ikan tengadak hasil silang luar (JK dam KJ) saling bersinggungan satu sama lain.

\section{Performa pertumbuhan ikan tengadak hasil silang luar}

Bobot mutlak dari empat populasi ikan tengadak hasil silang luar disajikan pada Gambar 3. Bobot mutlak menunjukkan nilai yang tidak berbeda nyata $(\mathrm{P}>0,05) \quad$ berkisar antara $0,49 \pm 0,08$ hingga 0,72 $\pm 0,05 \mathrm{~g}$.

Panjang mutlak empat populasi ikan tengadak disajikan pada Gambar 4. Panjang mutlak berkisar antara $0,29 \pm 0,08$ hingga $0,98 \pm 0,69 \mathrm{~cm}$ menunjukkan nilai yang sama $(\mathrm{P}>0,05)$.

Laju pertumbuhan bobot spesifik empat populasi ikan tengadak disajikan pada Gambar 5. Laju pertumbuhan bobot spesifik menunjukkan nilai yang tidak berbeda nyata $(\mathrm{P}>0,05)$ setelah diuji statistik. Laju pertumbuhan bobot spesifik berkisar antara $0,06 \pm 0,01$ hingga $0,36 \pm 0,22 \%$.

Tingkat kelangsungan hidup empat populasi ikan tengadak disajikan pada Gambar 6. Tingkat kelangsungan hidup hibrida menunjukkan nilai yang sama $(\mathrm{P}>0,05)$ berkisar dari 90,00 $\pm 10,00$ hingga $100,00 \pm 0,00 \%$. Hibrida (JK) memiliki tingkat

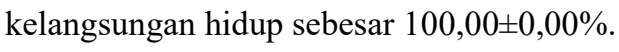


Tabel 1. Analisis Wilks lambda koefisien variasi pada 21 karakter morfometrik ikan tengadak hasil silang luar (Wilks lambda analysis coefficient of variation on 21 truss morphometric character of tinfoil barb from outbreed result).

\begin{tabular}{|c|c|c|c|c|c|}
\hline \multirow{2}{*}{$\begin{array}{c}\text { Karakter morfometrik } \\
\text { (Morphometric } \\
\text { character })\end{array}$} & \multicolumn{4}{|c|}{$\begin{array}{l}\text { Koefisien keragaman (\%) } \\
\text { (Coefficient of variation) }\end{array}$} & \multirow{2}{*}{$\begin{array}{c}\text { Signifikan wilks } \\
\text { lambda } \\
\text { (Significant wilks of } \\
\text { lambda) } \\
\end{array}$} \\
\hline & $\mathrm{J}$ & $\mathrm{JK}$ & $\mathrm{KJ}$ & $\mathrm{K}$ & \\
\hline A1 & 11,871 & 9,235 & 10,683 & 18,283 & 0,081 \\
\hline A2 & 9,059 & 9,800 & 11,901 & 8,712 & $0,000 *$ \\
\hline A3 & 4,202 & 6,129 & 7,714 & 5,070 & 0,977 \\
\hline A4 & 9,774 & 9,580 & 9,272 & 14,975 & $0,018^{*}$ \\
\hline A5 & 5,404 & 7,889 & 11,054 & 5,124 & $0,010^{*}$ \\
\hline A6 & 5,420 & 6,311 & 8,172 & 5,887 & $0,001^{*}$ \\
\hline B1 & 5,183 & 8,810 & 8,889 & 4,464 & 0,086 \\
\hline B2 & 4,403 & 6,087 & 7,334 & 5,435 & 0,159 \\
\hline B3 & 6,918 & 6,969 & 7,694 & 5,818 & $0,000 *$ \\
\hline B4 & 9,276 & 8,481 & 11,876 & 12,001 & 0,092 \\
\hline B5 & 6,126 & 6,507 & 9,086 & 5,008 & $0,000 *$ \\
\hline $\mathrm{C} 1$ & 10,131 & 13,654 & 18,684 & 9,179 & $0,000 *$ \\
\hline $\mathrm{C} 2$ & 4,955 & 6,270 & 8,466 & 5,853 & $0,000^{*}$ \\
\hline $\mathrm{C} 3$ & 7,326 & 6,721 & 8,978 & 5,039 & $0,000 *$ \\
\hline $\mathrm{C} 4$ & 11,157 & 14,151 & 16,416 & 8,080 & $0,000 *$ \\
\hline $\mathrm{C} 5$ & 5,773 & 7,980 & 8,389 & 6,544 & $0,000^{*}$ \\
\hline D1 & 7,211 & 7,958 & 8,343 & 8,559 & $0,000 *$ \\
\hline D2 & 5,143 & 8,491 & 7,491 & 6,220 & $0,000 *$ \\
\hline D3 & 11,170 & 8,620 & 10,995 & 11,833 & $0,010^{*}$ \\
\hline D4 & 11,814 & 11,527 & 15,451 & 17,485 & $0,000 *$ \\
\hline D5 & 14,916 & 11,934 & 9,832 & 9,737 & $0,011^{*}$ \\
\hline
\end{tabular}

Keterangan (note): *) berbeda nyata (significantly different) $(\mathrm{P}<0,05)$.

Tabel 2. Nilai sharing component intra dan inter populasi ikan tengadak hasil silang luar (Intra-inter population sharing component value of tinfoil barb from outbreed result).

\begin{tabular}{|c|c|c|c|c|c|}
\hline \multirow{2}{*}{$\begin{array}{c}\text { Populasi } \\
\text { (Population) }\end{array}$} & \multicolumn{4}{|c|}{$\begin{array}{l}\text { Nilai sharing component } \\
\text { (Sharing component value) }(\%)\end{array}$} & \multirow{2}{*}{$\begin{array}{l}\text { Jumlah } \\
\text { (Total) }\end{array}$} \\
\hline & $\mathrm{J}$ & JK & KJ & $\mathrm{K}$ & \\
\hline $\mathrm{JJ}$ & 93,3 & 0 & 0 & 6,7 & 100 \\
\hline JK & 0 & 86,7 & 13,3 & 0 & 100 \\
\hline $\mathrm{KJ}$ & 0 & 6,7 & 93,3 & 0 & 100 \\
\hline KK & 3,3 & 0 & 0 & 96,7 & 100 \\
\hline
\end{tabular}




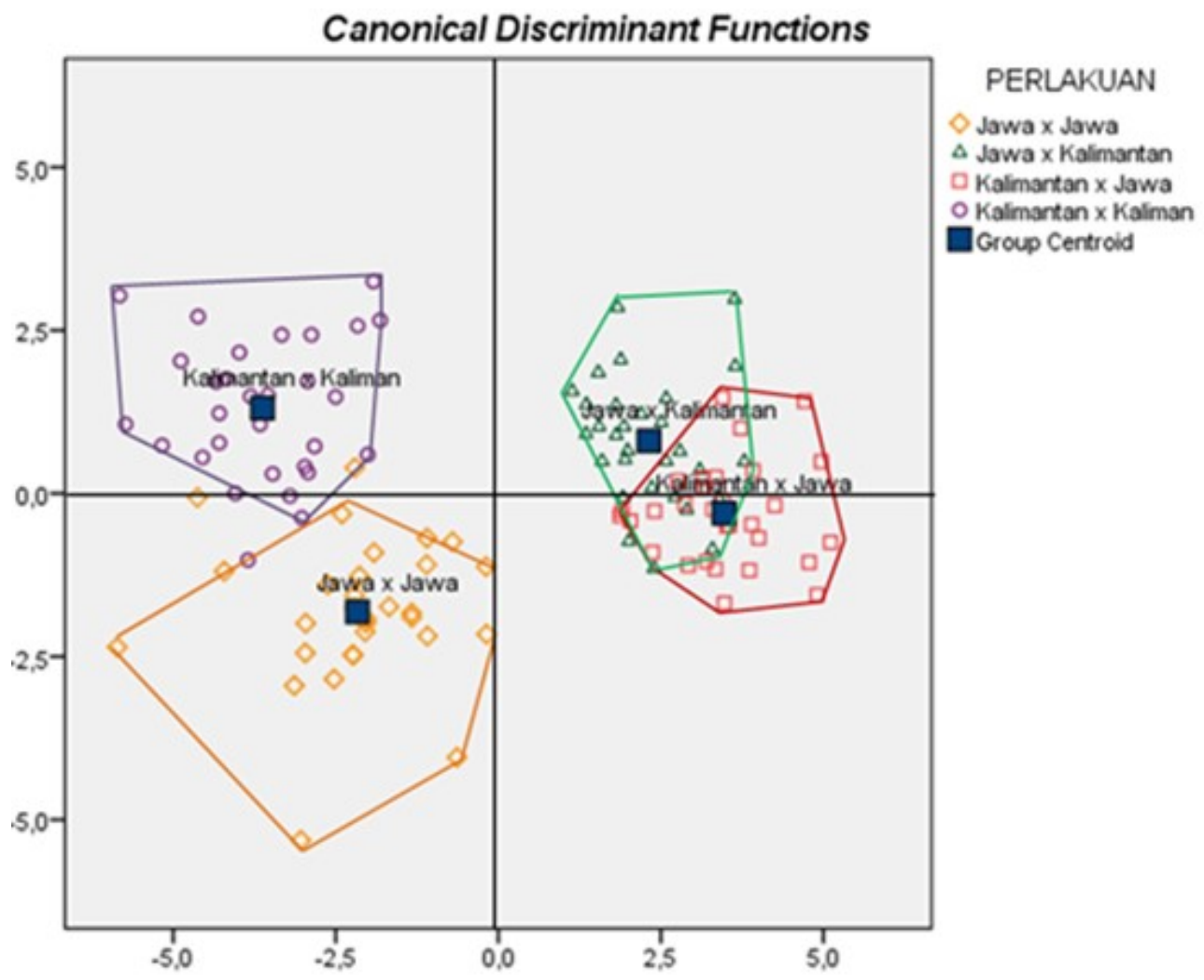

Gambar 2. Penyebaran karakter morfologi individu ikan tengadak hasil silang luar (Individual morphological characters distribution of tinfoil barb from outbreed result).

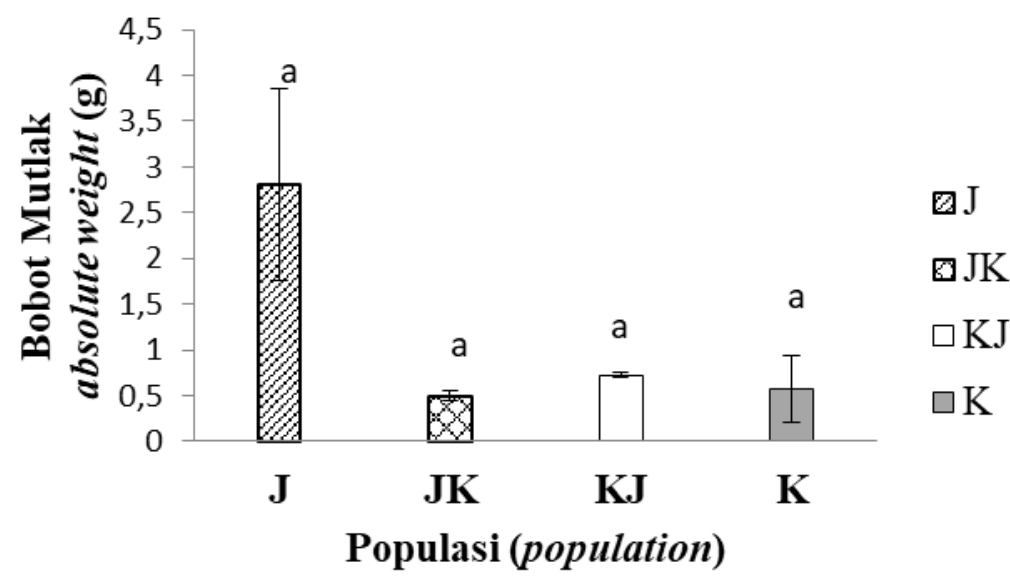

Gambar 3. Bobot mutlak ikan tengadak hasil silang luar (Absolute weight of tinfoil barb from outbreed result).

Keterangan (notes) : Huruf superskrip yang sama di atas bar menunjukkan hasil yang tidak berbeda nyata $(\mathrm{P}<0,05)($ The same superskrip letter on bar indicate not significantly difference). 


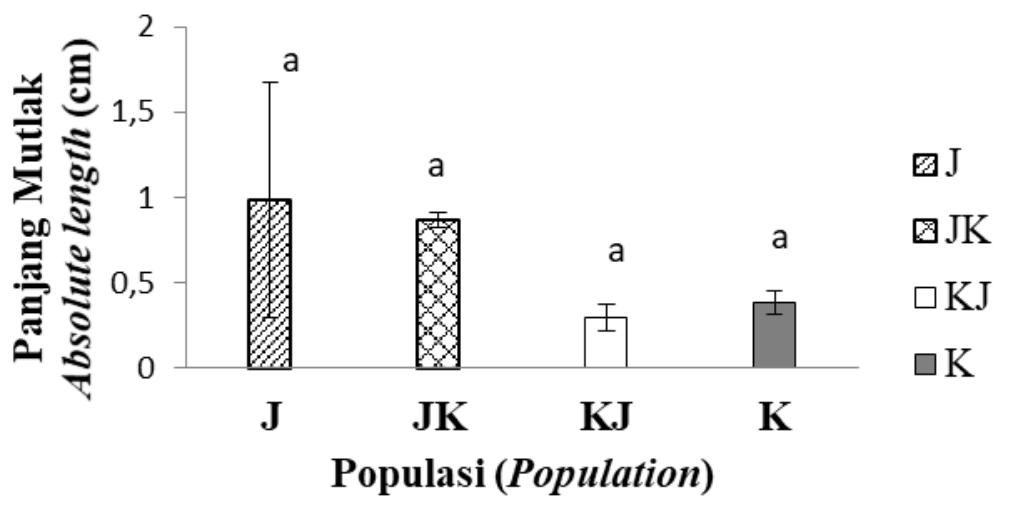

Gambar 4. Panjang mutlak ikan tengadak hasil silang luar (Absolute length of tinfoil barb from outbreed result).

Keterangan (notes): Huruf superskrip yang sama di atas bar menunjukkan hasil yang tidak berbeda nyata $(\mathrm{P}<0,05)($ The same superskrip letter on bar indicate not significantly difference).

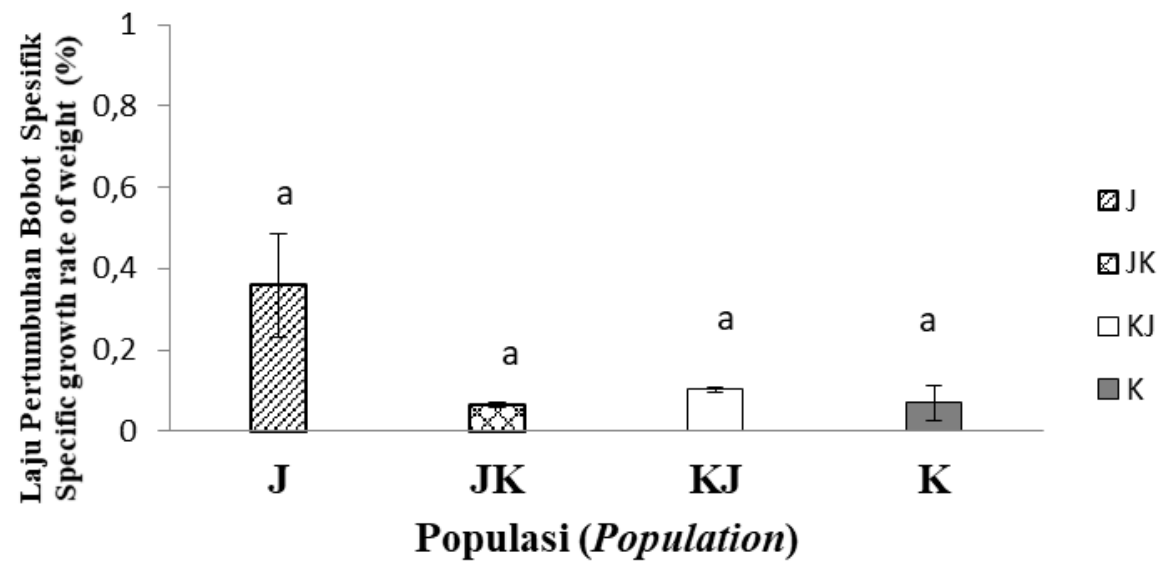

Gambar 5. Laju pertumbuhan bobot spesifik ikan tengadak hasil silang luar (Specific growth rate of weight on tinfoil barb from outbreed result).

Keterangan (notes): Huruf superskrip yang sama di atas bar menunjukkan hasil yang tidak berbeda nyata $(\mathrm{P}<0,05)($ The same superskrip letter on bar indicate not significantly difference). 


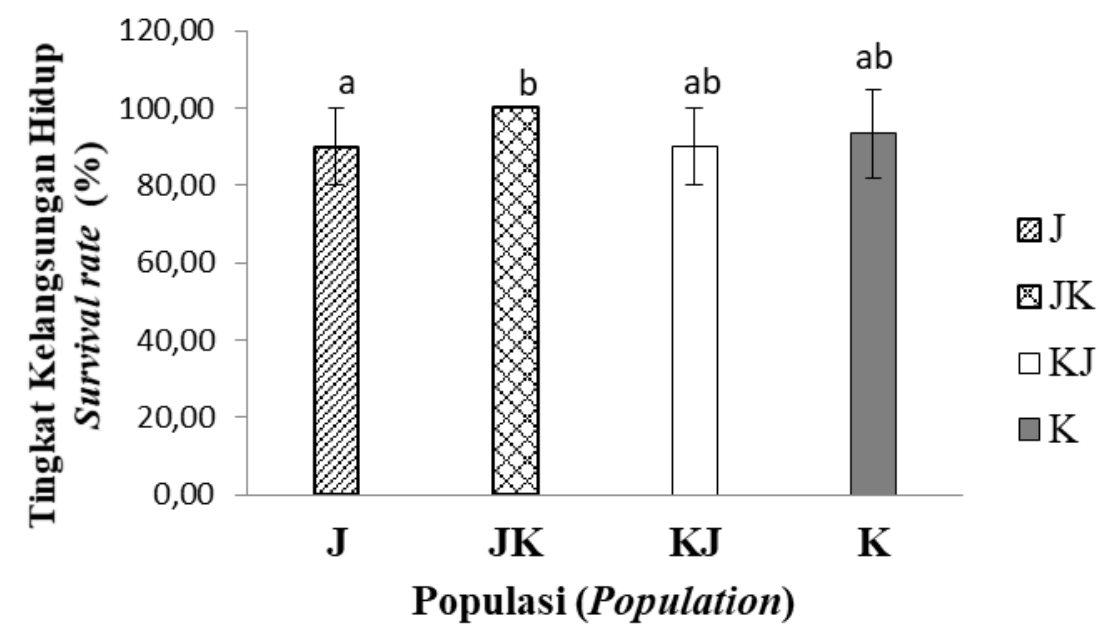

Gambar 6. Tingkat kelangsungan hidup ikan tengadak hasil silang luar (Survival rate of tinfoil barb from outbreed result).

Keterangan (notes): Huruf superskrip yang berbeda di atas bar menunjukkan hasil yang berbeda nyata $(\mathrm{P}<0,05)$ (Different superskrip letter on bar indicatae significantly difference).

\section{PEMBAHASAN}

\section{Truss morfometrik ikan tengadak hasil silang luar}

Berdasarkan uji signifikan karakter truss morfometrik antar populasi ikan tengadak untuk setiap karakter terdapat 16 karakter terukur yang memiliki karakter yang berbeda $(\mathrm{P}<0,05)$, kecuali $\mathrm{A} 1$ (ujung mulut - ujung operkulum bawah), A3 (ujung mulut - awal sirip perut), B1 (batas akhir tulang kepala - awal sirip punggung), B2 (batas akhir tulang kepala - awal sirip anal), dan B4 (awal sirip perut - awal sirip anal). Uji signifikan dibutuhkan untuk menentukan karakter yang digunakan sebagai karakter penciri (Kusmini et al., 2016). Hal tersebut mengindikasikan bahwa keempat populasi ikan tengadak memiliki 16 karakter pembeda dan lima karakter yang memiliki kesamaan. Nilai koefisien keragaman dari keempat populasi ikan tengadak berkisar antara 4,20-18,68\%. Nilai koefisien keragaman suatu karakter mengindikasikan tingkat keragaman karakter tersebut dalam suatu populasi (Falconer dan Mackay, 1996).

Rendahnya nilai sharing component intra populasi pada populasi hasil silang luar (JK) menunjukkan adanya keragaman genetik yang lebih tinggi dibandingkan dengan resiproknya $(\mathrm{KJ})$, serta populasi induk ( $\mathrm{J}$ dan $\mathrm{K}$ ). Sesuai dengan penuturan Mahardika et al. (2011), semakin tinggi nilai sharing component intra populasi, maka semakin rendah keragaman genetiknya, sedangkan nilai sharing component intra populasi yang semakin rendah menunjukkan keragaman genetik yang lebih tinggi.

Penyebaran karakter morfometrik pada ilustrasi fungsi kanonikal (Gambar 2) menunjukkan group centroid dari empat populasi berada di kuadran berbeda. Gambar di atas menunjukkan adanya kedekatan antara populasi hasil silang luar (JK) dan $(\mathrm{KJ})$. Hal itu ditunjukkan dengan garis dari kedua populasi hasil silang luar yang saling bersinggungan. Kemiripan yang terbentuk diduga karena keduanya mewarisi sumber genetik dari populasi induknya. Penyebaran karakter morfometrik pada ilustrasi fungsi kanonikal menunjukkan adanya kedekatan antara populasi hasil silang luar (JK) dan resiproknya $(\mathrm{KJ})$. Hal ini selaras dengan dendrogram jarak genetik yang menunjukkan jarak genetik kedua populasi hasil silang luar (JK dan KJ) adalah yang terdekat. Kemiripan antara kedua populasi hasil silang luar lebih besar dibandingkan dengan populasi induknya ( $\mathrm{J}$ dan $\mathrm{K}$ ). Diduga kemiripan yang 
terbentuk antara populasi hasil silang luar (JK) dan (KJ) karena keduanya mewarisi sumber genetik dari populasi induk yang sama. Sesuai dengan Dunham (2004) yang menyatakan bahwa, kedekatan hubungan kekerabatan yang terbentuk pada suatu populasi disebabkan adanya kesamaan sumber genetik pembentuk populasi.

\section{Performa pertumbuhan ikan tengadak hasil silang luar}

Parameter pertumbuhan (panjang dan bobot) menunjukkan hasil yang tidak berbeda nyata $(\mathrm{P}>0,05)$, sedangkan tingkat kelangsungan hidup menunjukkan hasil yang berbeda nyata $(\mathrm{P}<0,05)$ dengan nilai tertinggi pada populasi hasil silang luar (JK) sebesar 100,00 $\pm 0,00 \%$. Tingginya nilai tingkat kelangsungan hidup yang diperoleh pada populasi JK tersebut diduga karena adanya peran dari silang luar. Menurut Mahardika et al. (2011) dan Ath-thar et at. (2011), secara umum perkawinan tidak sekerabat dapat meningkatkan keragaan benih terutama tingkat kelangsungan hidup (TKH). Nilai yang sama $(\mathrm{P}>0,05)$ pada pertumbuhan diduga karena masa pemeliharaan yang kurang panjang sehingga perubahan yang terjadi pada populasi hasil silang luar masih belum tampak.

\section{KESIMPULAN}

Analisis fenotipe pada populasi hasil silang luar $q$ Jawa $\times \widehat{\sigma}$ Kalimantan menunjukkan nilai sharing component terendah sebesar $86,7 \%$ dengan performa kelangsungan hidup tertinggi (100\%).

\section{UCAPAN TERIMA KASIH}

Ucapan terimakasih diberikan kepada bapak Sudarmaji, ibu Fera Permata Putri dan Heppy Aprilistanto (Balai Riset Perikanan Budidaya Air Tawar dan Penyuluhan Perikanan) atas bantuan teknis selama penelitian.

\section{DAFTAR PUSTAKA}

Allen, D., 2012. Barbonymus schwanenfeldii. The IUCN Red

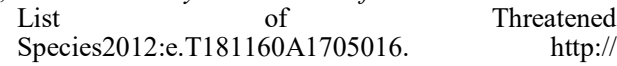
dx.doi.org/10.2305/ IUCN.UK.20121.RLTS.T181160A1705016.en. (Diakses 12 November 2017).
Ath-thar, M.H.F., Prakoso, V.A. dan Gustiano, R., 2011. Keragaan pertumbuhan hibridisasi empat strain ikan mas. Berita Biologi, 10(5), pp. 613-620.

Dewantoro, E., 2015. Keragaan gonad ikan tengadak (Barbonymus schwanenfeldii) setelah diinjeksi hormon HCG secara berkala. Jurnal Akuatika, 4(1), pp. $1-10$.

Dunham, R.A., 2004. Aquaculture and Fisheries Biotechnology: Genetic Approaches. Alabama (USA): CABI Publishing.

Falconer, D.S. and Mackay, T.F.C., 1996. Introduction to quantitative Genetic. Longman. Malaysia, p. 464.

Gustiano, R., Kusmini, I. dan Ath-thar, M.F.H., 2015. Mengenal Sumber Daya Genetik Ikan Spesifik Lokal Air Tawar Indonesia Untuk Pengembangan Budidaya. IPB Press, Bogor, p. 51.

Ismi, S., Asih, Y.N. dan Kusumawati, D., 2014. Peningkatan produksi dan kualitas benih kerapu dengan program hibridisasi. Jurnal Oseanologi Indonesia, 1(1), pp. 1 5

Kusmini, I.I., Gustiano, R., Radona, D., Prakoso, V.A., Putri, F.P. dan Prihadi, T.H., 2016. Karakterisasi fenotipe dan genotipe tiga populasi ikan tengadak, Barbonymus schwanenfeldii. Jurnal Riset Akuakultur, 11(3), pp. 207-216.

Kusmini, I.I., Gustiano, R., Mulyasari., Iskandariah dan Huwoyon, G.H., 2015. Ikan lokal tengadak (Barbonymus schwanenfeldii) asal Kalimantan sebagai andalan untuk ikan budidaya. Prosiding Seminar Nasional Ikan ke-8. Jakarta, Indonesia, pp. $177-187$.

Kusmini, I.I., 2009. Karakteristik fenotipe dan genotipe hibrida antara huna biru (Cherax albertisii) dengan huna capit merah (Cherax quadricarinatus). Tesis. Bogor Institut Pertanian Bogor.

Lorenzen, K., Beveridge, M.C.M. and Mangel, M., 2012. Cultured fish: integrative biology and management of domestication and interactions with wild fish Biology Review, 87, pp. 639-660.

Mahardika, P., Soelistiowati, D., Gustiano, R. dan Ath-thar, M.H.F., 2011. Keragaan hibrida intraspesifik dari empat strain ikan nila Oreochromis niloticus di karamba jaring apung, Danau Lido. Berita Biologi, 10(1), pp. 533-540.

Radona, D., Kusmini, I.I. dan Ath-thar, M.H.F., 2017. Karakteristik meristik dan morfometrik tiga generas ikan tengadak (Barbonymus schwanenfeldii) asa Kalimantan Barat, Indonesia. Jurnal Riset Akuakultur, 12(1), pp. 1-8.

Radona, D., Soelistyowati, D.T., Gustiano, T., Carman, O. Kusmini, I.I. dan Sundari, R., 2016. Ragam genotipe ikan tengadak (Barbonymus schwanenfeldii) persilangan populasi Jawa dan Kalimantan berdasarkan RAPD. Jurnal Riset Akuakultur, 10(2), pp. 99-105.

Radona, D., Soelistyowati, D.T., Carman, O., Gustiano, T., 2016. Keragaman genotipe dan morfometrik ikan tengadak (Barbonymus schwanenfeldii) asal Sumatera, Jawa dan Kalimantan. Jurnal Iktiologi Indonesia, 16(3), pp. 259-268.

Sneath, P.H.A., 1995. Thirty years of numerical taxonomy. Systematic Biology, 44, pp. 281-298.

Sunarma, A., 2016. Hibridisasi interpopulasi ikan lele afrika Clarias gariepinus yang diintroduksi di Indonesia Disertasi. Institut Pertanian Bogor.

Tave, D., 1993. Growth of triploid dan diploid bighead carp, Hypophthalmichthys nobilis. Journal of Applied Aquaculture. 2(2), pp. 13-25.

Wedemeyer, G., 2001. Fish Hatchery Management, second edition. Amerika Serikat: American Fisheries Society, Bethesda, Maryland, p. 751 